\title{
SEPT6 wt Allele
}

National Cancer Institute

\section{Source}

National Cancer Institute. SEPT6 wt Allele. NCI Thesaurus. Code C97783.

Human SEPT 6 wild-type allele is located in the vicinity of Xq24 and is approximately $80 \mathrm{~kb}$ in length. This allele, which encodes septin- 6 protein, plays a role in the regulation of cytoskeletal remodeling. Chromosomal rearrangements of this gene and the MLL gene are associated with acute myelogenous leukemia. 